\title{
Epidemiology of Small Ruminant Fasciolosis in Arid Areas of Lower Awash River Basin, Afar Region, Ethiopia
}

\author{
Hailegebrael Bedada $^{1,}$, , Fikru Gizaw ${ }^{1}$, Wossen Negash ${ }^{1}$, Angesom Hadush $^{1}$, Ali Wassie ${ }^{1}$, \\ Ashenafi Gebregergious ${ }^{2}$
}

${ }^{1}$ College of Veterinary Medicine, Samara University, Semera, Afar, Ethiopia

${ }^{2}$ Semera Veterinary Regional Laboratory, Semera, Afar, Ethiopia

\section{Email address:}

gorha2000@gmail.com (H. Bedada)

${ }^{*}$ Corresponding author

\section{To cite this article:}

Hailegebrael Bedada, Fikru Gizaw, Wossen Negash, Angesom Hadush, Ali Wassie, Ashenafi Gebregergious. Epidemiology of Small Ruminant Fasciolosis in Arid Areas of Lower Awash River Basin, Afar Region, Ethiopia. Animal and Veterinary Sciences. Vol. 5, No. 6, 2017, pp. 102-107. doi: 10.11648/j.avs.20170506.12

Received: April 12, 2017; Accepted: May 22, 2017; Published: November 5, 2017

\begin{abstract}
Across sectional study was conducted from December 2014 to February 2015 to determine the prevalence of Fasciolosis and associated risk factors of small ruminant in selected districts of Lower Awash River Basin. A total of 295 faecal samples were collected from (166 goat and 129 sheep), kept under pastoral and agro-pastoral area. Out of the total 295 faecal samples examined 32.5\% (259) were found positive to Fasciola infection. The result revealed that significantly higher prevalence of Fasciola infection was observed in goats $37.9 \%$ (63) than sheep 25.6\% (33). The risk of Fasciolosis in goats were 0.477 times higher than sheep $(\mathrm{OR}=0.477, \mathrm{p}<.048)$. Animals with poor body condition had higher $(44.5 \%)$ prevalence than animals with good body condition $(13.3 \%)$. Significantly $(\mathrm{OR}=3.513, \mathrm{p}<0.001)$ higher prevalence of disease was observed in animals managed under agro-pastoral production system than those kept in pastoral production. Like wise significant variation in prevalence was observed between the flocks contain both species of animal and contain only sheep or goat $(\mathrm{OR}=0.354$, $\mathrm{p}<0.036$ ). However, the prevalence of Fasciola infection was not significantly different between male and female animals. In the study area animal nutrition and social awareness on the importance of Fasciola infection is generally poor; low productivity in small ruminants is likely to be aggravated by a high prevalence of Fasciola. Hence, urgent and organized control strategies should be designed and implemented as milk of small ruminant is main source of food for pastoralists.
\end{abstract}

Keywords: Fasciola, Small Ruminants, Prevalence, Lower Awash, Afar

\section{Introduction}

Livestock production performs several functions primarily as source of household incomes, food and animal drought power for livestock producers (UNECA, 2012). It has been estimated that small ruminants provide up to $30 \%$ of the meat and $15 \%$ of the milk supplies in sub-Saharan Africa where thrive in the wide range of ecological regions which are too harsh for the beneficial rearing of cattle (Piedrafita et al., 2010). Small ruminants have also been reported to survive better under drought conditions than cattle due to their low body mass and low metabolic requirements which in turn minimize their water requirements and maintenance needed in arid and semi-arid areas. In spite of the large population and potential use of small ruminants in pastoral area, the production system is affected by feed shortage, poor genetic make up of the animals, and wide spread occurrence of livestock diseases such as endoparasites which have great economic significance to the communities and the country as a whole (UNECA 2012).

Ethiopian livestock production systems are broadly characterized as low input, mixed crop-livestock, agropastoral and pastoral systems; as well as medium input, periurban and urban enterprises (Sissay, 2007). Small ruminants represent the most important part of the Ethiopian livestock system, about 24.2 million sheep and 22.6 million of goats reported in the country (CSA, 2012). In pastoralist area, small ruminants are mainly utilized for milk and meat 
production and generate income to the owner.

Fasciolosis is an economically important disease of domestic livestock in particular ruminants. It is a trematode infection caused by the two major species of Fasciola: Fasciola hepatica and Fasciola gigantica. Recently worldwide losses in animal productivity due to Fasciolosis were conservatively estimated at over US 3.2 billion per annum (Mas-Coma et al., 2005). The prevalence of Fasciolosis in many parts of Africa has been determined mainly at slaughter. However, estimation of economic loss due to Fasciolosis at national or regional level is limited by lack of accurate estimation of the prevalence of disease. In addition Fasciolosis is now recognized as an emerging human disease. Fasciola species are one of the most important zoonotic diseases with a global economic impact in livestock production systems and a poorly defined but direct effect on human health (Piedrafita et al., 2010). The WHO has estimated that 2.4 million people are infected with Fasciola and 180 million are at risk of infection.

Small ruminant Fasciolosis in highland part of Ethiopia were studied by different researchers with the prevalence ranging from $11 \%-100 \%$. In this area of the country Fasciolosis is very frequent and causes a significant economic loss either in production or productivity (Chanie and Begashaw 2012; Rahmeto et al., 2010; Abunna et al., 2010; Jibat et al., 2008; Daniel, 1995). However, this important disease was usually overlooked not addressed and not assessed all over pastoral area of Lower Awash Rift Valley Afar. According to Yilma and Malone (1998) Irrigation would have major effects on transmission of Fasciolosis and in the study areas pastoralist also engaged on cultivation of plant by irrigation. Therefore, the objectives of this study were; (i) to investigate the current status of small ruminant Fasciolosis and determine associated risk factors in selected areas. (ii) to assess awareness of the pastoralist on the importance of small ruminant Fasciolosis in the study area.

\section{Material and Methods}

\subsection{Study Area and Population}

Investigation of Fasciolosis infections was carried out in two districts (Assayita and Dubti) of Lower Awash River Basin in Afar National Regional Sate. The Afar National Regional State is located in the Great Rift Valley, comprising range land in Northeast Ethiopia with an estimated area of $95,958 \mathrm{Km}^{2}$. The Region is located between $39^{\circ} 34^{\prime}$ and $42^{\circ} 28^{\prime}$ E longitude and $8^{\circ} 49^{\prime}$ and $14^{\circ} 30^{\prime} \mathrm{N}$ latitude. In the Afar Region, there are about 4.268,000 goats and 2.464,000 sheep, 2,420,488 heads of cattle, 903,630 camels and 193,317 equines which are managed under pastoral and agropastoral production system. The annual temperature and rainfall in the region is $30-50{ }^{\circ} \mathrm{C}$ and $200-600 \mathrm{~mm}$, respectively. The altitude of the region ranges from 116 meter below sea level to 1600 meters above sea level (ANRS, 2010).
Asayita district is located in between $11^{\circ} 34^{\prime} \mathrm{N}$ and $41^{\circ} 26^{\prime}$ E. The annual temperature and rainfall in the district is 28 $41.7^{\circ} \mathrm{C}$ and $144 \mathrm{~mm}$ annual precipitation, respectively. Asayita district located at an elevation of 340 meter above sea level (ANSR, 2010). In Asayita district there are about 97,013 goats, 17,198 sheep, 81,767 heads of cattle, 6108 camels and 3303 equines which are managed under pastoral and agro-pastoral production system. Dubti district contained about 49,234 goats, 24,363 sheep, 39,412 heads of cattle, 7241 camels and 2295 equines which are managed under pastoral and agro-pastoral production system. The production system in the area pre dominantly is pastoralism and agropastoralism (ANRS, 2010).

\subsection{Sampling Method and Sample Size Determination}

Across sectional study was employed from December 2014 to February 2015 to address the objectives of the study. The sampling method was supposed to be a multi-stage cluster sampling approach. However, due to the absence of between cluster variance and sampling frame in the study districts and pastoral community as a whole, unwillingness of pastoralists to include their animals in this study and conflict among pastoralists therefore, the flocks of small ruminants were sampled purposively. However, proportional allocation was used to distribute the individual sampled small ruminants evenly among the flock. Consequently, 5 to 10 individual animal from each small ruminants flock were sampled. Zone one was purposively selected based on the small ruminant population, ecology and accessibility to vehicle. The primary stage was sampling of districts from the selected zone. Selection of kebeles/PAs, flock and individual small ruminant within the flock were the $2^{\text {nd }}, 3^{\text {rd }}$ and $4^{\text {th }}$ stages, respectively. Accordingly, two districts and four kebeles/PAs from each district, proportional flocks from each Kebeles and 5 to 10 small ruminants from each flock was sampled. Therefore, total of 295 small ruminants (129 sheep and 166 goats) were included in this study. Each kebeles/PAs and individual animals from the flock sampled randomly. For questionnaire survey all owners (pastoralists) from which sample unit taken were included in the study.

\subsection{Sample Collection and Laboratory Examination}

Fresh fecal samples approximately $10 \mathrm{~g}$ were collected directly from the rectum of 295 small ruminant, samples placed in labeled sampling bottles and then after the collected samples were transported to laboratory for analysis. Following transportation of fecal sample laboratory analysis was carried out at the same day and the remaining samples were kept under $4^{\circ} \mathrm{C}$ and examined up on the next days. Coproscopic examinations were performed to detect Fasciola eggs using the standard sedimentation technique (Soulsby 1982, Hansen and Perry 1994). To differentiate between eggs of Paramphistomum species and Fasciola species, a drop of methylene blue solution was added to the sediment. Eggs of Fasciola species show yellowish brown with an indistinct operculum and embryonic cells, while eggs of 
Paramphistomum species is large and show transparent egg shell with distinct operculum and clear embryonic cells (Michael 2004).

\subsection{Data Analysis}

Data was recorded and entered to Microsoft Excel sheet and analyzed by using SPSS version 20. Chi square test and logistic regression were implemented to test the association between Fasciolosis and various risk factors (species, age, sex, body condition, production system and management).

\section{Results}

\subsection{Questionnaire Study Outputs}

A questionnaire was prepared in an attempt to obtain the general information on livestock ownership patterns, importance of small ruminant rearing, awareness about impact of Fasciolosis on production and productivity and the control practices implemented in the area. Response on livestock ownership pattern indicates that in both areas small ruminants mainly goat is the major species of animal kept by pastoralists for various reasons. The major reasons for keeping small ruminants were $57 / 57$ (100\%) for milk consumption at home as priority number one, priority number two were income generation and insurance 53/57 (92.9\%); $42 / 57$ (73.7\%) were kept small ruminants for meat consumption at home priority number three; $27 / 57$ (47.4\%) of pastoralists kept small ruminants for skin as priority number four. According to the respondents (100\%) manage small ruminants separately from other species of animal around their vicinity.

From the total 57 pastoralists interviewed only 8/57 (14\%) respondents knew Fasciolosis. However, only 3/57 (5.3\%) of respondents recognize the impact of Fasciolosis on animal production and productivities; among the major impacts mentioned by the pastoralist weight loss, death and reduction of milk yield were the principal one. All of the respondents those knew Fasciolosis replied there were no age difference on the occurrence of Fasciolosis it affects both adult and young. In general 57/57 (100\%) of respondents were have no idea about the transmission of disease and ecological impact on disease occurrence.

None of the pastoralists used modern treatment to control Fasciolosis as availability of modern veterinary service delivery is limited and their knowledge on modern veterinary importance is less (Figure 1).

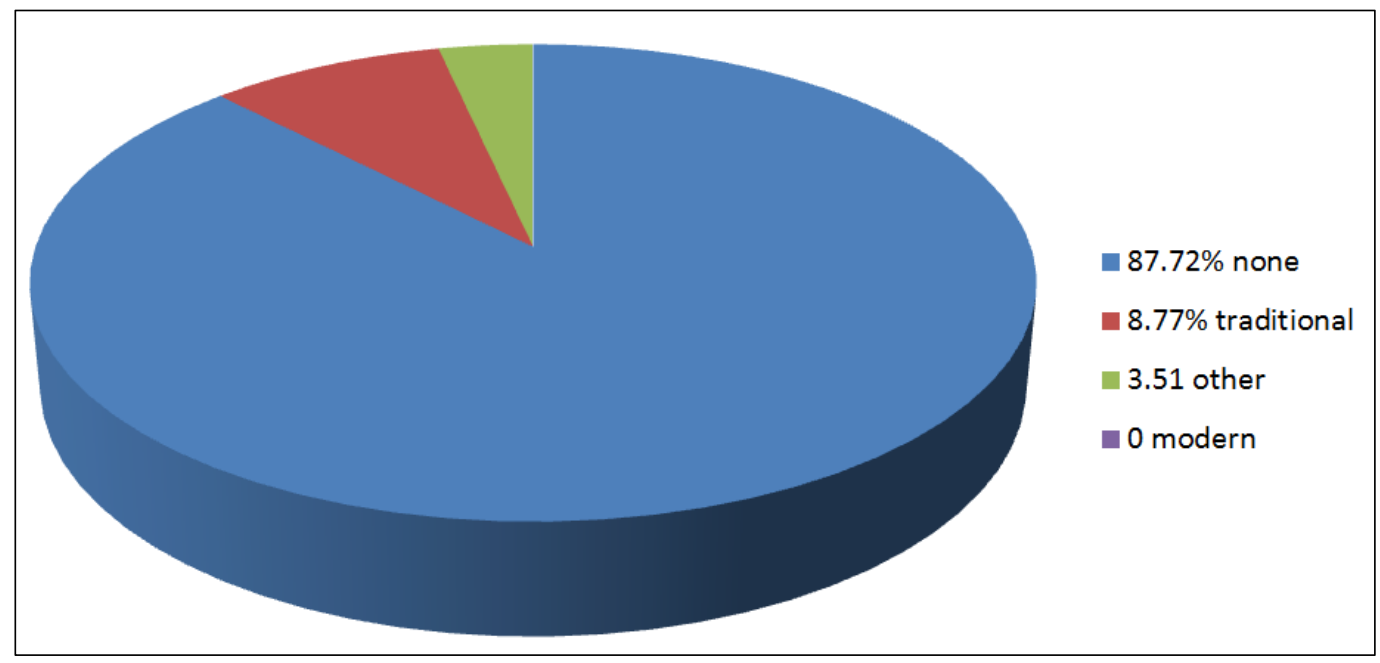

Figure 1. Proportions of respondent treatment method prefer to treat Fasciolosis in the study area.

\subsection{Results of Laboratory Findings}

Coprological examinations revealed out of 295 small ruminant examined $96(32.5 \%)$ were found to be positive for Fasciolosis. The specific prevalence of Fasciolosis in the study area was $37.9 \%$ in goat and $25.6 \%$ in sheep (Table 1 ).

\subsection{Production System and Management Based Prevalence}

The prevalence of Fasciolosis was $38.5 \%$ and $30.4 \%$ in small ruminants reared under agro-pastoral and pastoral production system respectively. Significance difference in prevalence of Fasciola infection $(\mathrm{OR}=3.513, \mathrm{P}<0.001)$ was observed between animals reared in agro-pastoral and pastoral area of the study (Table 1). The prevalence is significantly higher in the small ruminants kept under agro- pastoral production system. Like wise the prevalence of Fasciolosis was $38.1 \%, 25.9 \%$ and $24.7 \%$ in flock contain both sheep and goat, flock contains sheep only and flock contain goat only respectively. Statistically significance difference in prevalence of Fasciolosis was recorded among the flock contain both species and flock contain only each species separately $(\mathrm{OR}=0.354, \mathrm{P}<0.036)$ higher prevalence was recorded in flock contain both sheep and goat.

\subsection{Species Wise Prevalence}

The prevalence of Fasciolosis in goat and sheep of the study area was $37.9 \%$ and $25.6 \%$ respectively. Statistically significant variation in the prevalence of Fasciola infection was recorded between goat and sheep of the study area 
$(\mathrm{OR}=0.477, \mathrm{p}<0.048)$ higher in goat than sheep of the study area (Table 1).

\subsection{Sex Wise Prevalence}

Fasciolosis prevalence in female and male small ruminants of the study area was $32.8 \%$ and $32.1 \%$ respectively. Statistically significant variation in the prevalence of parasites was never recoded between male and female small ruminants of the study area $(\mathrm{p}>0.05)$ (Table 1$)$.

\subsection{Age Wise Prevalence}

The prevalence of Fasciolosis in young and adult animals of the study area was $24.3 \%$ and $37.5 \%$ respectively.
Significantly higher prevalence of Fasciolosis was recorded in adult animals than young animals $(\mathrm{OR}=0.490 ; \mathrm{p}<0.031)$ (Table 1).

\subsection{Body Condition Based Prevalence}

The prevalence of Fasciola infection in good and poor body condition animals was $13.3 \%$ and $44.5 \%$ respectively. Statistically significant difference in the prevalence of small ruminant Fasciolosis was recorded $(\mathrm{OR}=8.483$; $\mathrm{p}<0.000)$, higher in poor body condition animal than good body condition animals (Table 1).

Table 1. Summary of statistical results of small ruminant Fasciolosis in the study area.

\begin{tabular}{|c|c|c|c|c|c|c|c|c|}
\hline \multirow{2}{*}{ Category } & \multirow{2}{*}{ Variables } & \multirow{2}{*}{ Examined animals } & \multirow{2}{*}{ No of positive } & \multirow{2}{*}{$\%$} & \multirow{2}{*}{ P-value } & \multirow{2}{*}{ OR } & \multicolumn{2}{|c|}{ 95\% of CI for OR } \\
\hline & & & & & & & Lower & Upper \\
\hline \multirow{2}{*}{ Age } & Adult & 184 & 69 & 37.5 & \multirow{2}{*}{0.031} & \multirow{2}{*}{0.490} & \multirow{2}{*}{0.256} & \multirow{2}{*}{0.938} \\
\hline & Young & 111 & 27 & 24.3 & & & & \\
\hline \multirow{2}{*}{ Sex } & Female & 186 & 61 & 32.8 & \multirow{2}{*}{0.059} & \multirow{2}{*}{1.940} & \multirow{2}{*}{1.002} & \multirow{2}{*}{3.758} \\
\hline & Male & 109 & 35 & 32.1 & & & & \\
\hline Species & Goat & 166 & 63 & 37.9 & 0.048 & 0.477 & 0.229 & 0.954 \\
\hline \multirow{2}{*}{ Production system } & Pastoral & 217 & 66 & 30.4 & \multirow{3}{*}{0.001} & \multirow{3}{*}{3.513} & \multirow{3}{*}{1.713} & \multirow{3}{*}{7.206} \\
\hline & Agro-pastoral & 78 & 30 & 38.5 & & & & \\
\hline \multirow{3}{*}{ Management } & Goat only & 73 & 18 & 24.7 & & & & \\
\hline & Sheep only & 54 & 14 & 25.9 & \multirow[t]{2}{*}{0.036} & \multirow[t]{2}{*}{0.354} & \multirow[t]{2}{*}{0.160} & \multirow[t]{2}{*}{0.781} \\
\hline & Both & 168 & 64 & 38.1 & & & & \\
\hline Body condition & Good & 113 & 15 & 13.3 & 0.000 & 8.483 & .3 .934 & 18294 \\
\hline Total & & 295 & 96 & 32.5 & & & & \\
\hline
\end{tabular}

\section{Discussion}

Results presented in this study revealed overall prevalence of Fasciolosis is $32.5 \%$. The prevalence of Fasciolosis of the current study is inline with other reports from different parts of Ethiopia (Sirajudin et al., 2012; Manyazewal et al., 2013; Rubina et al., 2014). However, the current study result was much higher than the studies reported from different area (Adem, 1994; Daniel, 1995; Wassie, 1995; Michael 2004; Ahmed et al., 2007; Henok and Mekonnen, 2011; Abel et al., 2015) but it was lower than the finding in Ghana (Futagbi et al., 2015). The variation in prevalence might be due to the differences in temperature, moisture, humidity and also soil that might favor multiplication of intermediate snails host (Urquhart et al, 1994). Also the difference in prevalence and severity of the disease syndrome are evidence in various geographic regions depending on the local climatic condition, availability of permanent water (marshy area) and managemental practice of the area and agricultural irrigation practices. Irrigation based agricultural practice and the swampy areas are important ecologies for the continuity of the life cycle of Fasciolosis (Graber, 1975; Michael et al, 2005; Solomon, 2005).

The overall prevalence of Fasciolosis was significantly higher in caprine than ovine of the study area $(\mathrm{P}=0.048)$. Goats of the study area were 0.477 times at risk for the diseases than sheep. The current finding is in agreement with works of different researchers (Ahmed et al., 2005; Rubina et al., 2014). However, this finding is in contrary with other findings revealed Fasciolosis is higher in ovine than caprine (Michael, 2004; Dagnachew et al., 2011; Henok and Mekonnen, 2011; Yehualashet et al., 2013; Abel et al., 2015). Even though sheep and goats differ in their feeding habits, small ruminants are kept together on confined grazing land which may expose goats to acquire more susceptibility for Fasciolosis (Radostits et al., 2006). In consequence, the condition could be due to less or slow development of immunity in goats to the disease compared with the situation in sheep. Goats do not build up an effective immune response against helminth infections and so remain susceptible to disease throughout their lives. Sheep faced prolonged challenge over generations and had developed good resistance (Urquhart et al., 1996). The risk is enhanced if goats are forced to graze rather than browse (Urquhart et al., 1996; Radostits et al., 2006). Hence, in the study area recurrent drought occurred repeatedly and goats of the study area forced to graze as the bush become dry during this time and pastoralist provide their animals with grass collected from the irrigation channel as soon as they collect at dry 
season. Therefore, metacercariae encysted on the grass may get the access to be ingested by the goats. In addition pastoralists of the study area own different species of animals, and these animals share common watering points and grazing sites. The watering points of small ruminants are commonly shared with cattle and camel creating a close interspecies interaction among these domestic animals, and this might increases the risk of transmission of parasites which infect multiple species.

Age wise prevalence revealed a higher prevalence of Fasciolosis in adult animal than young one. This finding disagrees with most literatures that young animals are more susceptible to Fasciola infection than adult animals. However, agrees with reports from different parts (Ahmed et al., 2007; Henok and Mekonnen, 2011; Abel et al., 2015). This could be due to the fact that young animals are not allowed to go far with the adult animals for grazing. Therefore, the risk of exposure for infective metacercariae is reduced in young animals when compared to adults. In addition, in this study we ascribed the higher prevalence in adult might be due to the small number of young animals included in the study as the pastoralist interested to sale young animals since the society use small ruminant milk as a source of food for the household and if keep young they may not fulfill their necessity of using milk.

In this study a higher prevalence of Fasciola infection was recorded in poor body condition animals than good body condition animals. In the present study, the prevalence of Fasciolosis was 8.483 times higher in animals with poor body condition compared to those with good body condition score. This finding agrees with (Henok and Mekonnen, 2011; Sirajudin et al., 2012; Abel et al., 2015) indicated that animals with poor condition are highly susceptible to infection and may be clinically affected by worm burdens too small to harm an otherwise well-fed healthy animal. Moreover, this might be due to the fact that Fasciolosis cause weight loss and emaciation and/or shoats with poor body conditions are more susceptible to the parasite (Ahmed et al., 2005).

Higher prevalence of Fasciolosis was recorded in animals managed in agro-pastoral area than those managed in pastoral parts of the study area is attributable to the availability of irrigation channel and also the pastoralist provided grass collected from the channel as soon as collected therefore, the probability of infected by metacercariae is high. According to Yilma and Malone (1998) irrigation would have major effects on transmission of Fasciolosis. Consequently, irrigation based agricultural practice and the swampy areas are important ecologies for the continuity of the life cycle of Fasciolosis (Graber, 1975; Michael et al, 2005; Solomon, 2005). Likewise Fasciolosis was higher in areas were goats and sheep kept together than separately. Completion of life cycle eventually depends on how successfully the parasite can overcome complex interactions continually present in the environment and host. Fasciolosis is most common and widespread disease affecting all species of ruminant livestock (Radiostits et al., 2006). Therefore, keeping ovine and caprine together may favour for circulation of the disease in the flock as the parasite infect all ruminants.

\section{Conclusion}

The current study revealed that Fasciolosis was wide spread in small ruminants of pastoral and agro-pastoral parts of the study areas. The prevalence was significantly influenced by age, species, production system, and management system and body condition score of the small ruminants. In the study area pastoralists own different species of domestic animals, and these animals share common watering points and grazing pasture which creating a close interspecies interaction among these domestic animals, and this might increases the risk of transmission of Fasciola infection. In addition shortage of feed source in the study area special during prolonged drought magnified the occurrence and prevalence of Fasciola infection. Pastoralists of the study area are at risk of economic losses from decreased productivity of their animals as a majority of them have no idea about the impact of Fasciola infection. Thus, Fasciola infection should considered among diseases responsible for health and productivity problems in small ruminant. Detailed study on the economic and public health implications of Fasciola infection, molecular typing of Fasciola species circulating in the area and initiation of suitable control programs are recommended. Similarly strengthen awareness of the pastoralists on the importance, transmission way of disease, influence of ecology on disease occurrence and usage of modern treatment for Fasciola infection.

\section{Acknowledgements}

The authors acknowledge Samara University for all the financial and material supports we received. Especially we express gratitude to all workers of Samara Regional Veterinary Laboratory for their collaboration. We also thank the pastoralists for their cooperation during our work.

\section{References}

[1] Abel, B., Reta, T. and Samuel, D. 2015. Prevalence and Associated Risk Factors of Fasciola Infection In Small Ruminants Slaughtered at Addis Ababa Abattoir Enterprise, Ethiopia with Reference to Diagnostic Value of Its Coprological Examination. African J of Bas and App Sciences 7(4): 181-186, 2015.

[2] Abunna, F., Asfaw, L., Megersa, B. and Regassa, A. 2010. Bovine fasciolosis: coprological, abattoir survey and its economic impact due to liver condemnation at Soddo municipal abattoir, Southern Ethiopia. Trop. Anim. Health Prod. 42: 289-292.

[3] Ahmed, E. K., Markvichistr, S., Jumwasorn, S., Koonawoothtthin, S., Achoothesa, S. 2007. Prevalence of Fasciola species infections of sheep in the middle awash river basin. Ethiopian J. Tropical Medicine 38: 51-52. 
[4] Ahmed, S., Nawaz, M., Gul, R., Zakir M. And Razzaq, A. 2005. Diversity and revalence of Trematodes in Livers of Sheep and Goat in Quetta, Pakistan. Pak. J. Zool., 37: 205210.

[5] ANRS, "Afar National Regional State: Programme of Plan on Adaptation to Climate Change," Report, Semera. 2010. http://ebook browse.com/afar-national-regional-state climatechange-adaptation-program-pdf-d127720299.

[6] Central Statistic Agency (CSA). 2012. Federal Democratic Republic of Ethiopia, Central Statistical Agency Agricultural Sample Survey. Report on livestock and livestock characteristics; VolumeII, Addis Ababa, March 2012.

[7] Chanie, M. and Begashaw, S. 2012. Assessment of the Economic Impact and Prevalence of Ovine Fasciolosis in Menz Lalo Midir District, Northeast Ethiopia, Vet. World. 5(5): 261-264.

[8] Daniel, A. 1995. Economic importance of organ condemination due to Fasciolosis and Hydatidosis in cattle and sheep slaughtered at Diredawa Abattoir. DVM Thesis Faculty of Veterinary Medicine, Addis Ababa University, Ethiopia.

[9] Futagbi, G., Abankwa, J. K., Agbale, P. S. and Aboagye, I. F. 2015. Assessment of Helminth Infections in Goats Slaughtered in an Abattoir in asuburb of Accra, Ghana. West African J of Appl Eco, 23(2): 35-42.

[10] Graber, M. 1978. Helminths and helminthiasis of domestic and wild animals in Ethiopia. Revue Elev. Med. Vet. Pays Trop. 1: 13-95.

[11] Hansen, J. and Perry, B. 1994. The Epidemiology, Diagnosis and Control of Helminth parasite of Ruminants. A hand book. International Laboratory for research on Animal Disease (ILARD), Nairobi, Kenya.

[12] Henok, M. and Mekonnen, A. 2011. Study on the prevalence and risk factors of Fasciolosis in small ruminants in and around Hirna Town, Ethiopia. Global Veterinary, 7(5): 497501.

[13] Jibat, T., Ejeta, G., Asfaw, Y. and Wudie, A. 2008. Causes of abattoir condemnation in apparently healthy slaughtered sheep and goats at HELMEX abattoir, Debre Zeit, Ethiopia. Revue Médicine Vét 159(5), 305-311.

[14] Manyazewal, A., Zeleke, A., Tadesse, B. and Kumar, A. 2013. Epidemiology of Fasciolosis in Southwest, Ethiopia. Journal of Adv Vet Res 3: 127-134.

[15] Mas-Com, S., Brgues, M. D. and Valero, M. A. 2005. Fasciolosis and other plant borne trematode zoonoses. International J. parasitol., 35: 1255-1278.

[16] Michael, A. 2004. Infection prevalence of ovine Fasciolosis in irrigation schemes along the Upper Awash River Basin and effects of strategic anthelmintic treatment in selected up stream areas, MSc thesis, Addis Ababa University, Ethiopia.

[17] Phiri, I. K., Phiri, A. M. and Harrison, L. J. 2006. Serum antibody isotype response of Fasciola-infected sheep and cattle to excretory and secretary products of Fasciola species. Vet. Parasitol. 141: 234-42.

[18] Piedrafita, D., Spithill, T. W., Smith, R. E. and Raadsma, H. W. 2010. Improving animal and human health through understanding liver fluke immunology. Par Imm, 32: 572-581.

[19] Radiostits, O. M., Gray, C. C., Hinchelift, K. W. and Constable, P. D. 2007. Veterinary Medicine. A text book of the disease of cattle, horses, sheep, pigs and goats, $10^{\text {th }}$ edition. Sunders, Saunders Elsevier, London.

[20] Rahmeto, A., Fufa, A., Mulugeta, B., Solomon, M., Bekele, M. and Alemayehu, R. 2010. Fasciolosis: Prevalence, financial losses due to liver condemnation and evaluation of a simple sedimentation diagnostic technique in cattles laughtered at Hawassa Municipal abattoir, southern Ethiopia. Eth. Vet. J. 14(1): 39-51.

[21] Rubina, A., Muhammad, N. K., Muhammad, S. S. and Muhammad, T. J. 2014. Frequency Distribution of Fasciolosis in Small Ruminants Population at District Sargodha. Global Veterinaria 12(1): 26-32.

[22] Shimelis, D., Asmare, A. and Wudu, T. 2011. Epidemiology of gastro-intestinal helminthiasis of small ruminants in selected sites of North Gondar zone, Northwest Ethiopia. Ethiop. Vet. J. 15(2): 57-68.

[23] Sirajudin, K., Benti, D. and Worku, T. 2012. Small Ruminant Fasciolosis in Jimma Area of South Western Ethiopia: Its Epidemiology and Minimum Monetary Loss. Global Veterinaria 9(5): 635-641, 2012.

[24] Sissay, M. M. 2007. Helminth parasites of sheep and goats in eastern Ethiopia: Epidemiology, and anthelmintic resistance and its management. Doctoral thesis, Swedish University of Agricultural Sciences, Uppsala, Sweden.

[25] Soulsby, E. J. C. (1982): Helminthes, Arthropods and Protozoa of Domestic Animals, $7^{\text {th }}$ edition, Lea and Faebiger, Philadelphia.

[26] UNECA, 2012. Report on livestock value chains in eastern and southern Africa: a regional perspective, Addis Ababa, Ethiopia 19-21 November.

[27] Urquhart, G. M., Armour, J., Duncan, J. L., Dunn, A. M. and Jennings, F. W. 1996. Veterinary parasitology, $2^{\text {nd }}$ ed., Blackwell science Ltd, UK.

[28] Wassie, M. 1995. Prevalence of bovine and ovine Fasciolosis: a preliminary survey in Nekemte and its surrounding areas. DVM Thesis Faculty of Veterinary Medicine, Addis Ababa University, Ethiopia.

[29] Yehualashet, B., Aklilu, A., Kaleab, Z. and Tsegaye, A. 2013. Prevalence and economic importance of liver parasites: Hydatid Cyst, Fasciola species and Cysticercus tenuicolis in sheep and goats slaughtered at Addis Ababa abattoir enterprise in Ethiopia. $\mathrm{J}$ of Vet Med and Anim Health 5(1): 1-7.

[30] Yilma, J. M., and Malone, J. B. 1998. A geographic information system forecast model for strategic control of Fasciolosis in Ethiopia. Vet Parasito 78(2), 103-127. 